\title{
ANALISIS PROSPEK DAN KENDALA PENGEMBANGAN PRODUK INDUSTRI PANGAN LOKAL* DI SUMATERA BARAT
}

\author{
Gunarif Taib ${ }^{1}$ dan Rifda Roswita ${ }^{2}$ \\ ${ }^{1}$ Dosen Fakultas Teknologi Pertanian Universitas Andalas Padang \\ ${ }^{2}$ Penyuluh Balai Pengkajian Teknologi Pertanian Sumatera Barat \\ Email: gunariftaib@yahoo.com
}

\begin{abstract}
ABSTRAK
Komoditi pertanian di Indonesia belum sepenuhnya dikelola dengan optimal. Saat ini masih banyak komoditi pertanian yang dipasarkan dalam bentuk bahan segar sehingga belum menghasilkan nilai tambah yang bisa dinikmati oleh petani. Karena itu pengembangan industri, khususnya industri pangan lokal perlu dikembangkan. Dilihat dari peluang pasar yang ada, industri pangan lokal mempunyai prospek pasar yang baik. Namun demikian para pengusaha pangan lokal masih mempunyai kendala untuk mengembangkan industri pangan yang dimilikinya. Untuk merancang solusi yang tepat maka seluruh prospek dan kendala yang ada perlu dianalisis secara komprehensif. Untuk itu perlu dilakukan penelitian tentang prospek dan kendala pengembangan industri pangan lokal ini. Penelitian dilaksanakan pada sentra produksi pangan lokal di Sumatera Barat. Untuk mendapatkan data primer dilakukan indept interview dan Focus discussion Group dengan pemilik industri pangan lokal. Untuk optimasi faktor-faktor yang mempengaruhi pengembangan industri digunakan metode respon permukaan. Data penelitian yang diolah dengan program (Analytic Hierarchy Process) memperlihatkan bahwa produk industri pangan pangan lokal mempunyai prospek pengembangan dari sisi: citarasa $(0,3723)$, keragaman produk $(0,2643)$, skala usaha/bisa diusahakan dalam skala kecil $(0,2495)$, penunjang pariwisata/makanan oleh-oleh/souvenir bagi wisatawan $(0,1139)$. Kendala dalam pengembangannya adalah bahan baku/kontinyuitas pasokan $(0,3088)$, kualitas SDM/tenaga kerja $(0,2355)$, modal usaha $(0,1999)$, manajemen produksi dan pemasaran $(0,1448)$, standar mutu $(0,1110)$. Analisis data dengan menggunakan metode respon permukaan memperlihatkan bahwa pengembangan produk bisa dilakukan dengan melakukan optimasi berbagai faktor faktor kendala.

Kata kunci-industri, kendala, pengembangan, prospek
\end{abstract}

\section{PENDAHULUAN}

Industri pangan lokal, khususnya yang berskala kecil merupakan salah satu sumber pendapatan dari sebagian besar penduduk Sumatera Barat. Untuk mempercepat pengembangannya maka industri pangan lokal yang berskala kecil ini dibina dalam kelompok usaha yang tergabung dalam "Unit Pelayanan dan Pengembangan Pengolahan Hasil Pertanian (UP3HP)". Sampai tahun 2015 telah terbentuk sebanyak 160 kelompok usaha UP3HP yang berlokasi di berbagai Kabupaten/Kota di Sumatera Barat (Diperta Sumbar, 2016). Pembinaan industri pangan lokal ini dilakukan untuk mengatasi kelemahan yang dimilikinya.

Kelemahan industri pangan lokal ini antara lain adalah rendahnya penguasaan teknologi pengolahan. Adopsi teknologi industri pangan lokal ini masih rendah walaupun berbagai pelatihan telah dilaksanakan oleh instansi terkait (Taib, 2015). Hasil Penelitian Saikia (2012) menyatakan bahwa dalam berproduksi sebaiknya industri skala kecil menggunakan teknologi padat karya dan dalam penerapannya mengacu pada aspek finansial. Perpaduan antara aplikasi teknologi dengan aspek finansial merupakan jalan terbaik untuk mempercepat perkembangan usaha kecil.

Industri pangan lokal yang umumnya berskala kecil mempunyai potensi untuk meningkatkan nilai tambah produk pertanian. Untuk itu diperlukan usaha yang komprehensif untuk mengembangkan industri pangan lokal yanag skala kecil. Akan tetapi industri kecil ini belum bisa berkembang dengan baik. Hal ini disebabkan karena masalah yang berkaitan dengan pengadaan bahan baku, mutu produk dan pemasaran (Taib, 2014). Industri pangan lokal dalam skala kecil mempunyai potensi untuk dikembangkan, khususnya dalam era perdagangan bebas. Syukriah (2013) menyatakan bahwa usaha skala kecil di Indonesia mempunyai prospek yang baik di era perdagangan bebas "Masyarakat Ekonomi Asean", asalkan bisa memanfaatkan keunggulan komparatifnya, antara lain dengan 
meningkatkan inovasi teknologi guna menghasilkan produk yang khas, unik dan memberikan pelayanan yang baik.

Pramudyo (2014) menyatakan bahwa pada era Masyarakat Ekonomi Asean perlu dipersiapkan sumberdaya manusia yang tangguh. Untuk itu sangat perlu meningkatkan kemampuan hard skill dan soft skill. Dengan demikian dihasilkan tenaga kerja yang bisa bekerja efektif, efisien dengan keterampilan yang memadai. Untuk itu industri pangan lokal perlu memperhatikan kualitas sumberdaya manusia yang dimilikinya. Tyas (2014) menyatakan bahwa perdagangan bebas Asean memberikan peluang peningkatan taraf hidup masyarakat bila sumberdaya manusia dipersiapkan dengan baik. Akan tetapi bila tidak ada persiapan maka akan terjadi aliran barang dari luar negeri sehingga ancaman investasi dan tenaga kerja akan semakin mempersulit peningkatan daya saing produk Indonesia.

Daya saing produk pangan lokal harus ditingkatkan dengan memperhatikan berbagai kondisi yang mempengaruhi perkembangannya, khususnya tentang bagaimana adopsi teknologi pada proses produksi. Hasil penelitian Kuntariningsih (2014) membuktikan bahwa bahwa kondisi sosial, ekonomi dan kelembagaan mempunyai pengaruh yang signifikan terhadap adopsi teknologi. Teknologi yang digunakan harus memperhatikan faktor kearifan lokal. Selain itu penerapannya harus banyak memperhatikan keterlibatan masyarakat, hal ini harus diperhatikan dalam proses adopsi teknologi.

Wulandari (2012) menyatakan bahwa kecenderungan untuk menerapkan teknologi yang tinggi akan dipengaruhi oleh sikap pengguna teknologi. Kondisi ini berhubungan dengan rendahnya adopsi teknologi. Karena itu pengembangan industri pangan lokal yang dilakukan harus dilakukan dengan memperhatikan kemampuan pemilik industri dalam meningkatkan teknologi. Selain itu juga diperlukan terobosan untuk mengembangkan produk baru.

Dalam pengembangan produk harus diperhatikan berbagai faktor yang berkaitan dengan prospek yanag ada. Prospek dilihat dari berbagai sisi antara lain citarasa, keragaman produk, skala usaha (bisa diusahakan dalam skala kecil), pariwisata (makanan oleh-oleh/souvenir bagi wisatawan). Selain itu perlu juga diperhatikan berbagai kendala yang ada seperti kontinyuitas bahan baku (mutu dan jumlah), kualitas SDM (tenaga kerja), modal usaha, manajemen usaha (manajemen produksi dan pemasaran), standar mutu (sanitasi, SOP/standar pengolahan, kemasan).

\section{METODOLOGI PENELITIAN}

\section{A. Sumber Data}

Data primer diperoleh dari sentra produksi industri pangan lokal yang berada di Sumatera Barat. Untuk itu dilakukan indept interview dan Focus discussion Group dengan para pemilik industri pangan lokal. Industri yang dijadikan sebagai sumber data diseleksi dengan memperhatikan beberapa hal penting seperti kontinyuitas produksi, konsistensi dalam penggunaan bahan baku lokal dan skala usaha. Data untuk komparasi tingkat kepentingan parameter diperoleh dari wawancara dengan pakar yang mengetahui tentang perkembangan industri pangan lokal. Sedangkan data sekunder diperoleh dari institusi yang terkait dengan operasional industri pangan lokal.

\section{B. Analisis Data}

Data yang diperoleh dianalisa dengan menggunakan program Analytic Hierarchy Process (AHP.) Hal ini dilakukan untuk mengetahui tingkat kepentingan setiap variabel berdasarkan nilainya. Parameter pada setiap komponen diuji secara berpasangan. Pada pengujian ini dilihat parameter mana yang lebih penting. Tingkat kepentingan ditentukan berdasarkan skala kepentingannya. Komparasi data dilakukan untuk mengetahui konsistensi indeks serta konsistensi rasio matriks pada pendapat individu. Kemudian matriks pendapat individu yang konsisten bisa digunakan untuk membuat matriks gabungan. Program AHP digunakan untuk mengetahui tingkat kepentingan seluruh parameter. Hasil analisis data dijadikan sebagai acuan untuk menentukan peluang pengembangan produk.

Untuk melihat pengaruh berbagai parameter terhadap pengembangan produk maka data dianalisis dengan metode respon permukaan dengan rancangan central composite design (CCD). Lima variabel dalam peningkatan penjualan yaitu bahan baku, modal usaha, manajemen, kuaalitas SDM, standar mutu. Respon dari pengembangan produk digunakan untuk mengembangkan sebuah model matematis yang berkolerasi dengan bahan baku, modal usaha, manajemen, kuaalitas SDM, standar mutu. polinomial sebagai berikut: 
$Y=\beta o+\sum_{j=1}^{3} \beta i X i+\sum_{i j=1}^{3} \beta i j X i x j+\sum_{j=1}^{3} \beta j j X j 2$

keterangan: $Y$ adalah perkiraan nilai respon, $x i$ dan xj mewakili peubah-peubah, $\beta \mathrm{j}$ adalah efek linear, $\beta \mathrm{ij}$ adalah efek interaksi, $\beta \mathrm{jj}$ adalah efek kuadratik.

\section{HASIL DAN PEMBAHASAN}

\section{A. Prospek Pengembangan}

Dengan potensi sumberdaya manusia yang ada maka Indonesia mempunyai peluang yang besar untuk meningkatkan ekspor ke berbagai negara Asean. Untuk itu maka pengembangan agribisnis harus dilakukan dengan mengutamakan peran petani, pelaku usaha, penguasaan teknologi, pengembangan sarana prasarana serta kelembagaan di pedesaan (Kemendag RI, 2015). Untuk memanfaatkan peluang ini maka industri pangan lokal mempunyai prospek yang baik untuk dikembangkan. Penelitian yang dilakukan memperlihatkan bahwa faktor yang harus diperhatikan dalam pengembangan produk adalah citarasa citarasa $(0,3723)$, keragaman produk $(0,2643)$, skala usaha/bisa diusahakan dalam skala kecil $(0,2495)$, penunjang pariwisata/makanan oleh-oleh/souvenir bagi wisatawan $(0,1139)$. Untuk lebih jelasnya dapat dilihat pada Gambar1 berikut ini.

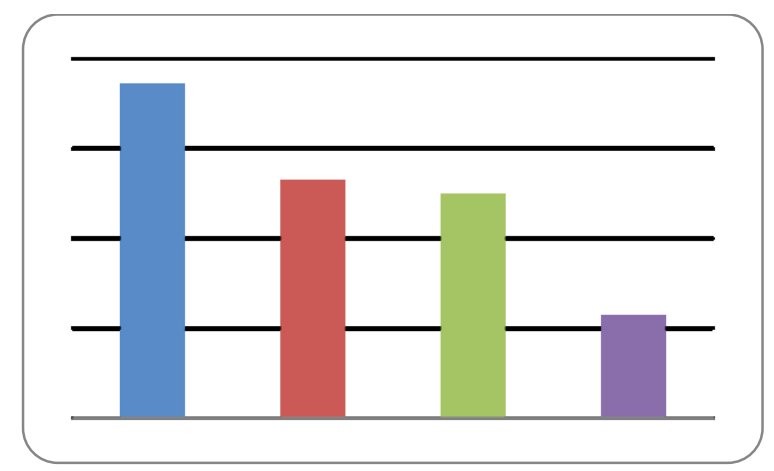

Gambar 1. Prospek Pengembangan

\section{B. Kendala Pengembangan}

Peningkatan jumlah penduduk dan perubahan pola konsumsi akan meningatkan permintaan terhadap bahan pangan. Dalam hal ini harus selalu diperhatikan faktor gizi dan keamanan pangan. Kondisi ini merupakan peluang bagi industri pangan untuk meningkatkan produktifitasnya guna mengantisipasi ketersediaan pangan di tingkat global (Capone, 2014). Untuk itu dalam pengembangan produk pangan lokal perlu diperhatikan berbagai hal yang terkait dengan peluang pengembangan tersebut. Penelitian yang dilakukan memperlihatkan bebagai faktor yang bisa menjadi kendala dalam pengembangan produk pangan lokal antara lain adalah kontinyuitas pasokan bahan baku $(0,3088)$, kualitas SDM/tenaga kerja $(0,2355)$, modal usaha $(0,1999)$, manajemen produksi dan pemasaran $(0,1448)$, standar mutu $(0,1110)$. Bobot dari masing-masing faktor yang menjadi kendala dalam pengembangan produk pangan lokal, khususnya di Sumatera Barat dapat dilihat pada Gambar 2 berikut ini.

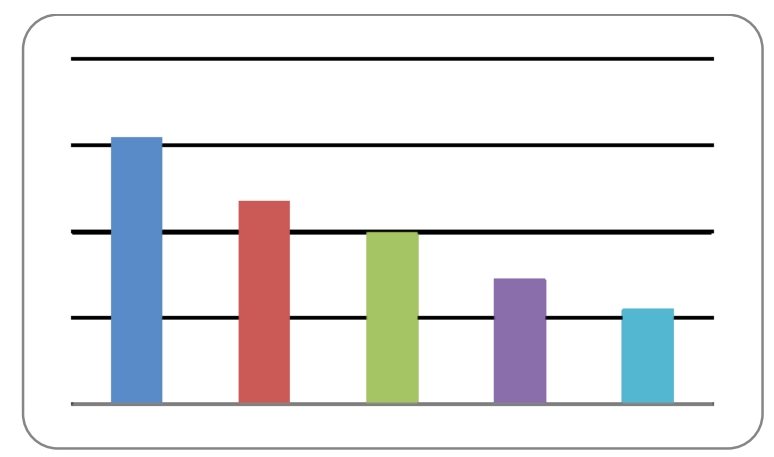

Gambar 2. Kendala dalam Pengembangan 


\section{Pengembangan Produk Pangan Lokal}

Penegembangan produk harus dilakukan dengan memperhatikan potensi yang ada dan kendala yanag berpotensi menjadi penghambat. Dalam pengembangan produk pangan lokal, khususnya di Sumatera Barat harus disesuaikan dengan ketersediaan bahan baku dan kualitas SDM yang ada. Hal ini dilakukan agar keberlanjutan usaha bisa terjamin. Gbigbi (2017) menyatakan bahwa keberlanjutan usaha skala kecil berkaitan dengan faktor pendidikan, jenis kelamin, luas lahan, agunan, frekuensi transaksi serta keanggotaan koperasi. Selain itu juga harus ada kebijakan untuk mendorong perbankan dan sumber keuangan mikro agar bisa mempertimbangkan petani dalam mengakses kredit. Kondisi ini diperlukan untuk meningkatkan output, pendapatan dan produktivitas petani kecil. Interaksi antara kualitas SDM dan ketersediaan bahan baku dan dampaknya terhadap pengembangan produk dapat dilihat pada Gambar 3 berikut ini.

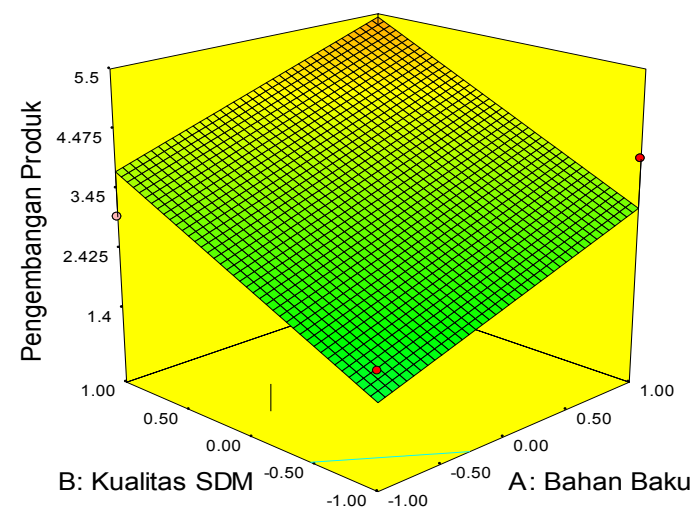

Gambar 3. Pengaruh Bahan Baku dan Kualitas SDM terhadap Pengembangan Produk

Selanjutnya modal usaha juga perlu diperhatikan dalam usaha pengembangan produk pangan lokal. Modal usaha tidak hanya dibutuhkan untuk pengembangan industri pangan lokal, akan tetapi juga dibutuhkan untuk kegiatan usaha tani guna menjaga kontinyuitas pasokan bahan bakunya. Nyamekye (2016) menyatakan bahwa pertanian sangat berpengaruh terhadap perekonomian dan penyerapan tenaga kerja. Keberhasilan dalam pengembangan komoditas pertanian berkaitan dengan pendidikan, modal dan akses terhadap penyuluhan. Interaksi berbagai faktor ini sangat berpengaruh terhadap peluang pengembangan produk. Pada Gambar 4 berikut ini bisa dilihat interaksi antara faktor modal usaha dan kontinyuitas pasokan bahan baku dan dampaknya terhadap pengembangan produk.

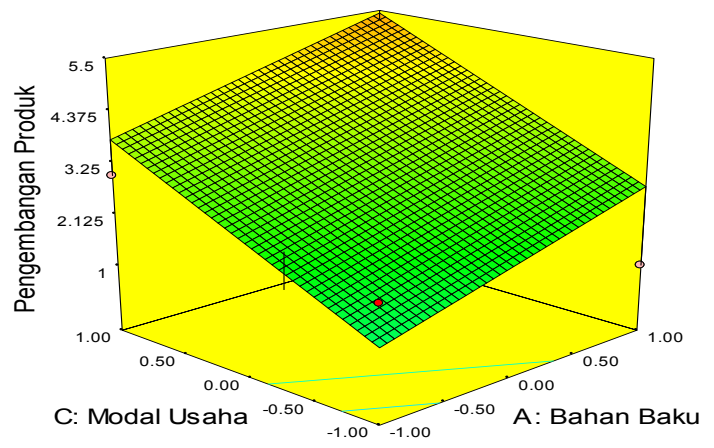

Gambar 4. Pengaruh Modal Usaha dan Bahan Baku terhadap Pengembangan Produk

Untuk pengembangan selanjutnya diperlukan kemampuan manajerial dari pemilik industri pangan lokal. Untuk itu pemerintah melalui institusi terkait diharapkan bisa melakukan berbagai pelatihan untuk meningkatkan kemampuan pemilik usaha dalam hal manajemen. Kemampuan manajerial juga perlu dikembangkan untuk meningkatkan kapasitas pemilik usaha dalam hal berinteraksi dengan pihak lain seperti pihak swasta yang berkaitan dengan peluang pemasaran produk 
pangan lokal. George (2014) menyatakan bahwa untuk mengembangkan industri pengolahan pangan diperlukan sinergi antara pemerintah, swasta dan pelaku usaha. Hal ini sangat diperlukan untuk pengembangan teknologi yang diperlukan pada industri pangan. Sumberdaya alam berupa komoditas pertanian yang selama ini tidak dibudidayakan dengan baik, harus dikelola secara baik. Pada Gambar 5 berikut ini bia dilihat interaksi antara faktor manajemen dan bahan baku serta pengaruhnya terhadap pengembangan produk.

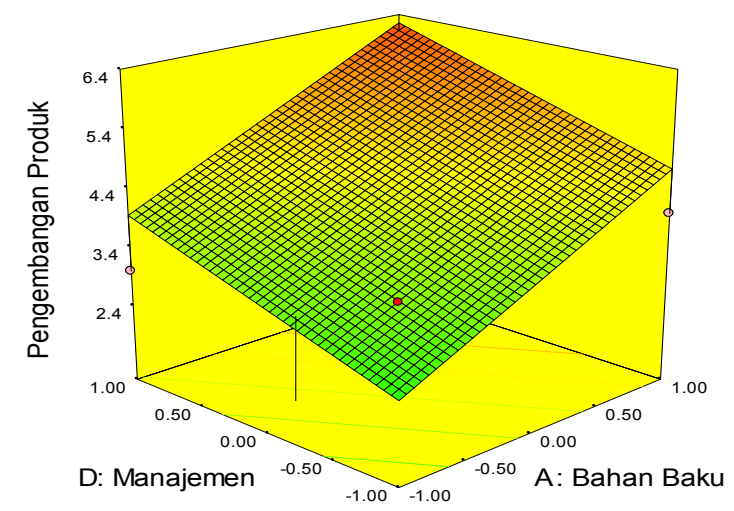

Gambar 5. Pengaruh Manajemen dan Bahan Baku terhadap Pengembangan Produk

Mutu produk juga merupakan faktor penentu dalam pengembangan produk pangan lokal. Saat ini industri pangan lokal masih belum menerapkan standar mutu dengan baik. Hal ini mengakibatkan daya saing menjadi berkurang. Standarisasi produk belum dilakukan dengan baik sehingga keseragaman produk belum bisa diperoleh. Standar mutu juga diperlukan untuk melakukan diferensiasi produk yang merupakan salah satu terobosan yang biasa dilakukan oleh pemilik industri. Putra (2017) menyatakan bahwa untuk pengembangan industri makanan diperlukan diferensiasi produk. Selain itu juga harus melakukan promosi dengan memanfaatkan berbagai media dan dibantu oleh kebijakan pemerintah dalam pengembangan potensi industri makanan ringan ini.

Pengembangan produk juga dilakukan dengan tujuan mewujudkan ketahanan pangan. Hal ini berkaitan dengan salah tujuan industri pangan yang dapat memenuhu kebutuhan pangan rumahtangga. Sahu (2017) menyatakan bahwa indeks ketahanan pangan berkaitan aspek sosio-ekonomi seperti pendapatan rumahtangga dan ukuran keluarga. Hal ini juga berkaitan dengan keragaman konsumsi keluarga, pola konsumsi pangan, dan kemandirian pangan. Karena itu pengembangan industri pangan lokal mempunyai peranan yang sangat strategis dalam mewujudkan ketahanan pangan keluarga dengan menghasilkan produk pangan yang bermutu baik. Pada Gambar 6 berikut ini bisa dilihat interaksi antara standar mutu dengan bahan baku serta hubungannya dengan pengembangan produk.

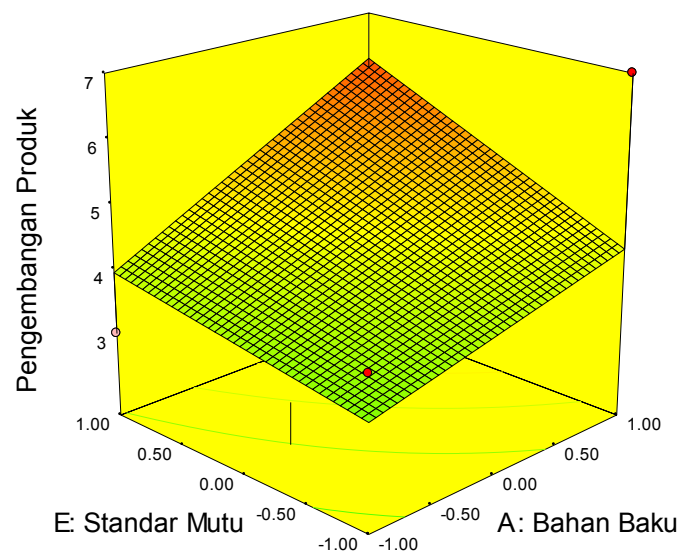

Gambar 6. Pengaruh standar mutu dan bahan baku terhadap pengembangan produk 


\section{KESIMPULAN}

Dari penelitian yang dilaksanakan bisa diambil kesimpulan yang berkaitan dengan pengembangan produk. Adapun kesimpulan yang bisa diambil adalah sebagai berikut :

1. Pengembangan produk pangan lokal harus dilakukan dengan memperhatikan keunggulan berupa citarasa produk, keragaman produk, perkembangan pariwisata

2. Kendala dalam pengembangan produk pangan lokal adalah kontinyuitas bahan baku, modal usaha, kualitas SDM, manajemen dan standar mutu.

3. Faktor yang harus diperhatikan dalam pengembangan produk adalah citarasa citarasa, keragaman produk, skala usaha/bisa diusahakan dalam skala kecil, penunjang pariwisata/makanan oleholeh/souvenir bagi wisatawan.

\section{UCAPAN TERIMA KASIH}

Penulis mengucapkan terimakasih kepada semua pihak yang memfasilitasi terlaksananya penelitian ini, khususnya kepada pimpinan Fakultas Teknologi Pertanian Universitas Andalas padang. Selain itu juga disampaikan terima kasih kepada Kepala Dinas Tanaman Pangan, Hortikultura dan Perkebunan Provinsi Sumatera Barat yang memfasilitasi pelaksanaan penelitian di lapangan.

\section{DAFTAR PUSTAKA}

Capone. R. Bilali, H.e. Debs, P. Cardone, G. Driousech, N. 2014. Food System Sustainability and Food Security. Connecting The Dots. Journal of Food Security, 2014, Vol. 2, No. 1, 13-22.

Greoge, M. J. 2016. The Status of food Industry and Associated Socio-Economic Implications in Lesotho : Challenges and Oppportinities. Journal of Science Policy and Governance. September 2014, page $1-11$.

Kementerian Perdagangan Republik Indonesia. 2015. Peluang dan Tantangan Indonesia pada Pasar Bebas Asean Masyarakat Ekonomi Asean. Warta Ekspor Edisi Januari 2015, hal 17.

Gbigbi, Miebi, T. 2017. Are There Road Blocks to Access Micr0-credit From Selected Micrifnance Banks in Delta State, Nigeria? Implications for Small Scale Farmers Sustainability!

Nyamekye I, Fiankor, D., Ntoni. J. 2016. Effect of Human Capital on Maize Productivity in Ghana: A Quantile Regression Approach. International Journal of Food and Agricultural Economics ISSN 2147-8988, E-ISSN: 2149-3766. Vol. 4 No. 2, 2016, pp. 125-13.Pramudyo, A. 2014. Mempersiapkan Sumberdaya Manusia Indonesia Dalam Menghadapi Masyarakat Ekonomi Asean Tahun 2015. JBMA - Volume II, No 2 Semtember 2014.

Putra, S. 2017. Analisis Industri Pangan Sub Sektor Industri Makanan Ringan Kue bangkit dan Bolu. JOM Fekon UNRI, Vol 4, No 1 Tahun 2017.

Sahu, A.K., Zhopnu, Chuzo, Das,s. 2017. Measuring Household Food Security Index for High Hill. Journal of Food Security, 2017, Vol. 5, No. 5, 155-161

Syukriah, A. Imam, H. 2013. Peningkatan Eksistensi UMKM Melalui Comparative Advantage Dalam Rangka Menghadapi MEA 2015 di Temanggung. Economic Development Analysis Journal, EDAJ 2 (2) (2013).

Taib, G. 2014. Evaluation in Component Technology Small Scale Food Industry Cluster in West Sumatera. International Journal on Advanced Science, Engineering and Information Technology. Volume 4 (2014) No 2.

Taib. G. 2015. International Journal on Advanced Science, Engineering and Information Technology. Volume 5 (2015) No 2.

Tyas, A.A.W.P, Safitri, V.I. 2014. Penguatan Sektor UKM Sebagai Strategi Menghadapi MEA 2015. Jurnal Ekonomi, Volume 5, No 1 Mei 2014.

Wulandari, S., Eriyatno, Rusli, M.S., Kusmuljono, B.S. 2012. Model Proses Adopsi Teknologi di Agroindustri Lada Dengan Fuzzy Inference System. Optimasi Sistem Industri. 